\title{
中国北東部半乾燥地域の砂地草原における 放牧管理による植生・土壌の回復過程
}

\section{Vegetation and Soil Restoration Process by Grazing Control at Desertified Sandy Grassland in Semi-Arid Regions of Northeast China}

大黒俊哉* 根本正之*

Toshiya OHKURO Masayuki NEMOTO

摘要：過放牧による砂漠化が問題となっている中国内蒙古自治区奈曼を事例として，禁牧年数の異な る砂地草原での調査をもとに, 植生及び土壤の变化を地形条件との関連で把握したうえで, 放牧管理 による植生・土壤回復プロセスの立地間差異について検討した。本研究の結果, 植生分布およびその 動態は，地形条件と関連した土壤特性あるいは水分条件の差異に規定されることが示唆された。植生 および鎄の回復速度も地形条件によって異なり, 砂丘下部や平沙地では禁牧後速やかに回復へ向か うのに対し，砂丘中〜上部では，20 年程度の期間を要することがわかった。以上の結果に基づき， 地形タイプごとに持続的土地利用のあり方について検討した。

\section{1.はじめに}

不適切な人間活動に起因する上地の荒廃は，「砂漠化」に代表 されるように，現在グローバルスケールで進行しており，地球環 境や食糧供給への深刻な影響が懸念されている。日本をとりまく 東アジア地域に扔いても，爆発的な人口増加を背景に，各地で士 地荒廃が大きな問題となっている ${ }^{2212}$ 。とりわけ多様な気候地域 を持つ中国では, 北西部の乾燥地域の周辺から南部の湿潤地域ま で，さまざまな要因による土地荒廃が引き起こされている。

土地荒廃が生じると，土地生産力が低下するばかりでなく，加 速的な進行プロセスによって被害地域が連鎖的に拡大していくこ とが多い7)。そのため中国でもこれまでは，その進行を食い怖め るための緑化技術の開発が最優先の課題之されてきた ${ }^{6226)}$ 。一方, 本来気候的に植生が成立する地域であれば，放牧や農地之しての 利用を制限あるいは禁止することにより，遷移の進行を促進して 植生の回復を図ることが可能である ${ }^{19}$ 。しかし，その回復のプロ セスや速度は土地条件により大きく異なる ${ }^{521120)}$ 。したがって荒 廃地の修復を効果的かつ経済的に行うためには, あらかじめ個々 の立地ごとに自然潜在力を把握したうえで，緑化技術屯含めて最 適な修復手法を適用していくことが望まれる。こうした自然潜在 力の推定はまた, 適正な土地利用コントロールを行う際のゾーニ ングの指針としても有効と考えられる。

過放牧は，過耕作や森林伐採などとともに，土地荒廃をもたら す主要なインパクトのひとつである ${ }^{24)}$ 。中国では北東部の半乾燥 地域を中心に，過放牧による荒廃地がみられるが，なかでも砂地 草原では, 植生が一旦破壊されると砂丘の再活動が引き起こされ るため，植生の回復は非常に困難となる ${ }^{26)}$ 。砂地草原に抢ける植

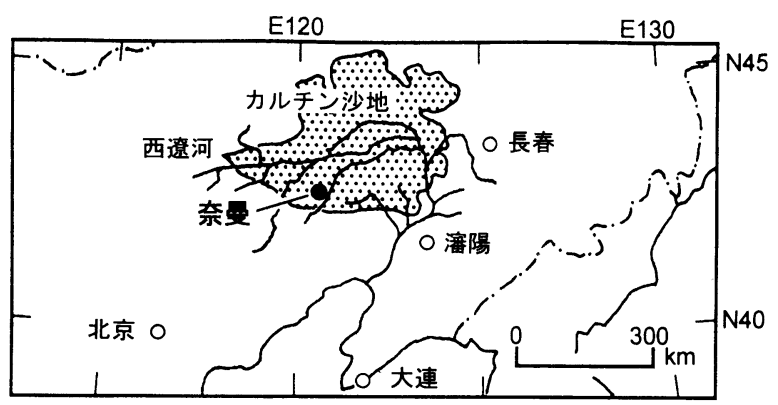

図ー1 カルチン沙地および調査地 (奈曼) の位置図
生の分布求よび退行・吅復過程は，地形条件によって異なるこ上 がすでに指摘されている ${ }^{(1) 201}$ 。しかし，自然潜在力を総合的に把 握するためには，植生のみならず，上㙵变化等のプロセスをも含 めた土地の回復過程を明らかにしておく必要がある。

本報告では，過放牧による砂漠化が問題となっている内蒙古自 治区奈曼を事例之して，禁牧年数の異なる砂地草原での調査を屯 とに, 植生および土壤の変化を主として地形条件との関連で把握 したうえで，放牧管理による植生・土壤回復のプロセスと土地利 用ポテンシャルの立地間差異について検討した。

\section{2. 調查地の概要と調查方法}

\section{（1）調査地の概要}

調查地として選定した内蒙古自治区哲里木盟余曼旗は，北京の 北東約 $500 \mathrm{~km}$ にあり，カルチン沙地とよばれる，西遼河・带に 広がる砂地草原の南部に位置し（図－1），カルチン沙地のなか でも砂漠化の進行が最も著しい地域のひとつとされている ${ }^{26)}$ こ の地域のキな表層堆積物は第四紀の砂質の湖沼堆積物であり，か つての乾燥父候期に移動して形成された砂丘が植牛により固定さ れている。年平均気温は $6 \sim 7^{\circ} \mathrm{C}$ ，年降水量は約 $370 \mathrm{~mm}$ であり， 降水量の 70\%は6〜9月の夏期に集中している。しかし，耕作， 放牧，薪の採取などの利用が過剩になる上，植生之上壤が破壊さ れて未固結の砂層が流動化し，砂漠化が進行する ${ }^{111}$ 。また春先に は，砂が移動を開始するとされる $5 \mathrm{~m} /$ 秒以上の北西季節風があ り，砂漠化を進行させる大きな要因のひとつとなっている。

上記のプロセスが顕著にみられるのは，主として起伏の大きい 砂丘地であり, 砂丘活動の程度に応じて, 固定砂斥, 半流動砂斤, 流動砂丘などに区分されている。一方，こうした砂丘地の間にみ られる起伏の小さい平坦地（平沙地）や，地下水位の高い平坦地 （低平地）は，放牧地のみならず耕地としての重要度も高いとさ れるが，植生退行・回復のプロセスや土地利用ポテンシャル等に 関する研究は十分なされていない。そこで本研究では，これらの 地形タイプのうち，砂丘地抢よび平沙地を対象として植生・土壤 の回復プロセスを調査することとした。

\section{(2) 調查方法}

現地調查は，砂丘地については 1994 年，平沙地では 1995 年の それぞれ 8 月下旬から 9 月上旬にかけて行った。まず，奈曼旗の ほぼ中心に位置する中国科学院沙漠研究所奈曼沙漠化研究站

*農業環境技術研究所保全植生研究室 
$\left(42^{\circ} 55^{\prime} \mathrm{N}, 120^{\circ} 42^{\prime} \mathrm{E}, 400 \mathrm{~m}\right.$ a.s.1.) 周辺において，聞き取り 調査打よび現地踏査を行い, 牧柵の設置により放牧管理が行われ ている草地を把握した。そのうえで, 禁牧年数が異なり（禁牧後 約 10 年, 20 年), かつ禁牧以前の植生の状態が類似していたとさ れる 2 地区の砂斥地を調相対象地区として選定した。禁牧約 10 年の地区 (以下禁牧 10年) は, 哲里木盟林業試験場の緑化事業の 一環として，1984年から牧柵が設置されている。一方，禁牧約 20 年（以下禁牧 20 年）の地区は鉄道沿いに位置し, 鉄道沿線への 砂丘の侵入を防止する目的で 1976 年より牧柵が設置されている。

また, 後者の地区と牧柵を境界として隣接し, 現在む放牧が行 われている砂丘地を，対照区（以下放牧砂丘地）として選定した。 地形, 種組成, 植被率等に関する聞き取り調査や哲里木盟林業試 験場の情報から, この放牧砂丘地は, 牧柵が設置される以前の上 記 2 地区にほぼ近い状態であると推定された。

一方，平沙地については，現在も放牧が行われている場所（以 下放牧平沙地）と，それ之隣接して 1992 年より試験的に牧柵が 設置されている場所（以下禁牧 4 年）について, 調査を行った。 砂丘地の各調査地区では，代表的な砂丘斜面を含む $120 \mathrm{~m} \sim 180 \mathrm{~m}$ 程度のラインを設置し, 各ラインに沿って, $5 \mathrm{~m}$ ご とに $1 \mathrm{~m} \times 1 \mathrm{~m}$ のコドラートを設定して, 群落高 $(\mathrm{cm})$, 植被率 （\%), 各出現種の自然高 $(\mathrm{cm})$ および被度（\%)を測定した。 平沙地については，放牧平沙地では $220 \mathrm{~m}$ のラインを $20 \mathrm{~m}$ 間隔 で，禁牧 4 年では $200 \mathrm{~m}$ のラインを $25 \mathrm{~m}$ 間隔でそれぞれ 2 本平 行に設置し, 各ラインに沿って $20 \mathrm{~m}$ ごとに $1 \mathrm{~m} \times 1 \mathrm{~m}$ のコドラー トを設定して，上記と同様の調査を行った。土堙については，全 コドラートで山中式土裹硬度計を用いて地表の土猿硬度を測定す るとともに, 表層から $5 \mathrm{~cm}$ の範囲の土㙵を採取し, 後の分析に 供した。さらに, 斜面測量器 (東京りサーチサービス製) を用い て，上記ラインに浻って簡易地形測量を行ったうえで, 各コドラー トの地形特性をあらわす指標として, 比高および起伏量を計算し た。前者は, 主として斜面の相対的な位置を示す值であり ${ }^{17}$, 各 調查地区におけるライン上の最低点 $(0 \mathrm{~m})$ に対する各コドラー トの高度差と定義した。なお, 各調査地区の最低点での地下水位 は, 禁牧 10 年で $1.5 \mathrm{~m}$, 放牧砂丘地および禁牧 20 年で $2.0 \mathrm{~m}$, 放牧平沙地および禁牧 4 年で $3.0 \mathrm{~m}$ であり，これらの值に比高を 加えた值が各コドラートの地下水面からの距離に相当する。また 後者は, 勾配を示す值として, 各コドラートを中心としたライン 上 $10 \mathrm{~m}$ の範冊における最高点と最低点との高度差と定義しだ。

採取した土㙵は，粒径分布および全炭素・全窒素の測定に供し た。粒径分析については, 国際土㙵学会法の粒径区分のうち, 粗 砂および細砂を一括したうえで, 砂 $(2.0 \sim 0.02 \mathrm{~mm})$, シルト $(0.02 \sim 0.002 \mathrm{~mm})$, 粘土 $(<0.002 \mathrm{~mm})$ の割合をピペット法に より測定した"。また全炭素・全窒素については，CN コーダー （柳本製作所）を用いた乾式燃焼法により測定した1)。

植生調査によって得られた種組成データについてはまず，群集 解析で用いられる分類手法である TWINSPAN により群落夕 イプの分類を行い，植生構造のおおよそのパターンを把握した。 つぎに, 植生・土壤回復と地形条件の関係について詳細な解析を 行うために，地形条件の変化に富んだ砂斥地のサンプルのみを対 象として，プログラム CANOCO を用いて Canonical Correspondence Analysis (CCA) ${ }^{23)}$ を行った。CCA は, 環境条件 に関するデータを参照しながら対応分析の結果を補正し，サンプ ル，種抢よび環境条件の 3 者の関係を同時に分析する直接傾度分 析手法のひとつである ${ }^{922) 。}$

\section{3. 結果}

(1) TWINSPAN による群落タイプの区分

植生調查地点は, 砂丘地が 84 地点, 平沙地が 44 地点で, 合計

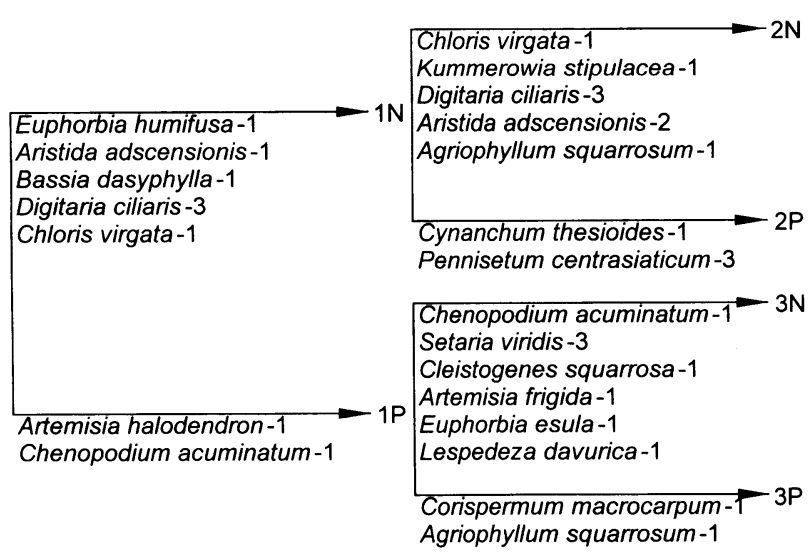

図ー2 TWINSPANによるスタンド群の分割過程と分割に使 用された区分種 (pseudospecies)

種名の右側の数字は被度階級（表-1参照）を示す

表ー 1 TWINSPAN 第 2 分割で区分されたスタンド群におけ る種の出現傾向

\begin{tabular}{|c|c|c|c|c|c|}
\hline \multirow[t]{2}{*}{ 種 名 ${ }^{* 1}$} & \multirow[t]{2}{*}{ 略名 } & \multicolumn{4}{|c|}{ TWINSPAN分類 ${ }^{* 2}$} \\
\hline & & $2 \mathrm{~N}$ & $2 \mathrm{P}$ & $3 \mathrm{~N}$ & $3 \mathrm{P}$ \\
\hline Agriophyllum squarrosum & $\mathrm{ASq}$ & 1 & 1 & $\cdot$ & 1 \\
\hline Aneurolepidium dasystachys & $\mathrm{AD}$ & 1 & 1 & $\cdot$ & $\cdot$ \\
\hline Tribulus terrestris & TT & 1 & $\cdot$ & $\cdot$ & $\cdot$ \\
\hline Chloris virgata & $\mathrm{CV}$ & 5 & 1 & $\cdot$ & • \\
\hline Kummerowia stipulacea & KS & 2 & 2 & 1 & $\cdot$ \\
\hline Aristida adscensionis & $\mathrm{AA}$ & 4 & 3 & 1 & $\cdot$ \\
\hline Bassia dasyphylla & $\mathrm{BD}$ & 1 & 1 & 1 & • \\
\hline Euphorbia humifusa & EH & 1 & 2 & 1 & $\cdot$ \\
\hline Calamagrositis epigeios & $\mathrm{CE}$ & $\cdot$ & 1 & $\cdot$ & $\cdot$ \\
\hline Phragmites australis & PA & 1 & 4 & 1 & 1 \\
\hline Erodium stephanianum & ES & 1 & 3 & 1 & $\cdot$ \\
\hline Pennisetum centrasiaticum & $\mathrm{PC}$ & 2 & 4 & 3 & 1 \\
\hline Salsola collina & $\mathrm{SC}$ & 1 & 3 & 2 & 1 \\
\hline Lespedeza davurica & LD & 2 & 3 & 3 & 1 \\
\hline Artemisia scoparia & $\mathrm{ASc}$ & 1 & 2 & 3 & $\cdot$ \\
\hline Digitaria ciliaris & $\mathrm{DC}$ & 4 & 4 & 2 & 1 \\
\hline Eragrostis pilosa & $\mathrm{EP}$ & 1 & 1 & 1 & 1 \\
\hline Ixeris chinensis & IC & 1 & 1 & 1 & 1 \\
\hline Corispermum macrocarpum & $\mathrm{CMa}$ & 1 & 1 & 1 & 1 \\
\hline Cynanchum thesioides & $\mathrm{CT}$ & 1 & 1 & 1 & 1 \\
\hline Melissitus ruthenicus & MR & 1 & 2 & 2 & 2 \\
\hline Setaria viridis & SV & 3 & 4 & 5 & 1 \\
\hline Cleistogenes squarrosa & $\mathrm{CS}$ & 1 & 1 & 2 & $\cdot$ \\
\hline Caragana microphylla & $\mathrm{CMi}$ & $\cdot$ & 1 & 2 & 1 \\
\hline Chenopodium acuminatum & $\mathrm{CA}$ & $\cdot$ & 1 & 2 & $\cdot$ \\
\hline Hedysarum fruticosum & $\mathrm{HF}$ & $\cdot$ & $\cdot$ & 2 & $\cdot$ \\
\hline Ranunculus chinensis & $\mathrm{RC}$ & - & 1 & 1 & $\cdot$ \\
\hline Artemisia frigida & $\mathrm{AF}$ & $\cdot$ & 1 & 3 & $\cdot$ \\
\hline Euphorbia esula & $\mathrm{EE}$ & 1 & 1 & 2 & $\cdot$ \\
\hline Artemisia halodendron & $\mathrm{AH}$ & 1 & 2 & 4 & 5 \\
\hline Equisetum ramosissimum & ER & $\cdot$ & 1 & 1 & 1 \\
\hline Ferula bungeana & FB & $\cdot$ & 1 & 1 & 1 \\
\hline コドラート数 & & 26 & 29 & 45 & 28 \\
\hline
\end{tabular}

※1:10回以上出現した種を示した。

$※ 2$ : 各スタンド群での平均被度を 5 段階の階級

$(1:<2 \%, 2: 2-5 \%, 3: 5-10 \%, 4: 10-20 \%, 5: 20 \%<)$ で示した.

128 地点のコドラートのサンプルが得られた。また, 全出現種数 は 58 種であった。

まず, 全サンプルを対象に, 出現 3 回以上の種の被度デー夕を 用いてTWINSPAN による群落区分を行った。図一 2 に TWINSPAN 分割過程と各分割に使用された種を示した。また 表一 1 に, 第 2 分割で区分された各スタンド群における種の出現 傾向を示した。第 1 分割では，主として Aristida adscensionis， Digitaria ciliaris, Chloris virgata といったイネ科の一年草 


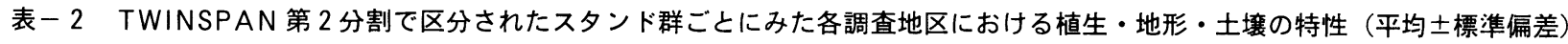

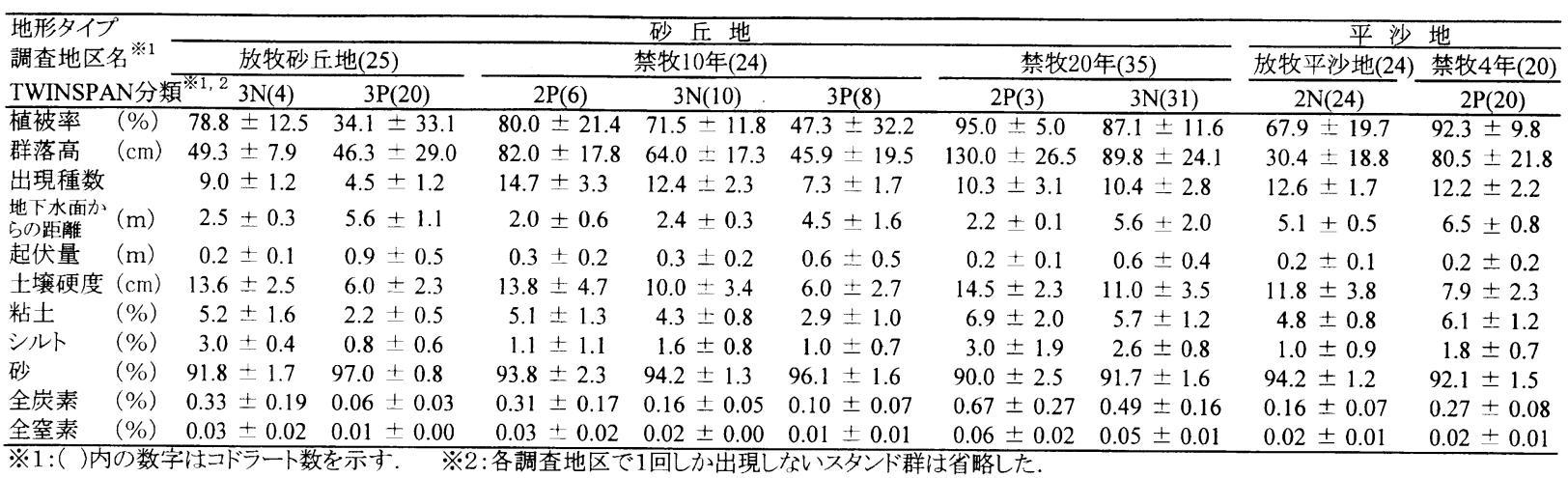

により区分される $1 \mathrm{~N}$ と，ヨモギ属の Artemisia halodendron 等によって区分される $1 \mathrm{P}$ に分割された。第 2 分割では, $1 \mathrm{~N}$ は上記のイネ科一年草に加え，アカザ科のAgriophyllum squarrosumによって区分される $2 \mathrm{~N}$ と，イネ科の多年草であ るPennisetum centrasiaticum 等によって区分される $2 \mathrm{P} に$ 分割された。また $1 \mathrm{P} は, \exists モ キ ゙$ 属の Artemisia frigida, イ ネ科多年草の Cleistogenes squarrosa 等により区分される $3 \mathrm{~N}$ と, アカザ科の Corispermum macrocarpum, Agriophyllum squarrosum により区分される3P のスタンド群にそれぞ れ区分された。

つぎに表一 2 に, 各調査地区における植生, 地形, 土壤の各特 性を出現スタンド群ごとに示した。

まず砂丘地をみると, 放牧砂丘地では, 地下水面からの距離お よび起伏量の小さい砂丘下部の平坦面を除いてすべて 3 P に区分 された。植被率は平均で約 $35 \%$ であったが，70\%以上に達する 地点から $5 \%$ 以下の裸地に近い地点まで含まれており, コドラー トあたりの出現種数は 5 種程度ときわめて少なかった。また土倳 についても，粘土含量，全窒素（C）打よび全炭素（N）ともに きわめて低い值を示した。禁牧 10 年でも，地下水面からの距離 が $2.5 \mathrm{~m}$ 前後の地点は $3 \mathrm{~N}$ に，それより大きい地点は $3 \mathrm{P}$ に区分 され，放牧砂丘地とほぼ同様の傾向を示し，3 P では依然として 植被率の低い地点もみられた。一方, 地下水面からの距離が $2 \mathrm{~m}$ 前後の地点では, 2 P のタイプも出現した。植被率, 群落高, 種 数は $3 \mathrm{P}<3 \mathrm{~N}<2 \mathrm{P}$ の順に増加する傾向を示し, 粘土含量, C および $\mathrm{N}$ も記の順に増加した。これに対し禁牧 20 年では，砂 丘下部の一部が 2 P に区分されたほかは, 地下水面からの距離の 大きい地点もすべて $3 \mathrm{~N}$ に区分された。植被率は $90 \%$ 程度に達 し，粘土含量， C および $\mathrm{N}$ も顕著な增加が認められた。

一方, 平沙地をみると, 放牧平沙地は $2 \mathrm{~N}$ に, 禁牧 4 年は $2 \mathrm{P}$ に，それぞれすべてのサンプルが含まれた。放牧平沙地では放牧 圧の影響を受けて群落高が低く抑えられたものの，植被率，種数 や粘土含量, C および $\mathrm{N}$ の值は砂丘地の $3 \mathrm{P}$ より大きく, 禁牧 10 年の砂丘下部にみられる $3 \mathrm{~N}$ と同程度の值を示した。また, 禁牧 4 年では植被率，群落高ともに顕著な回復が認められた。

(2) Canonical Correspondence Analysisによる解析

以上のように, 砂丘地では斜面の相対的位置により, 植生・土 壤の回復程度に差異か認められた。そこで, 砂丘地の 84 サンプ ルを対象に, 被度デー夕を用いて CCAによる解析を行った。環 境変数（Environmental variable）には，各コドラートにおけ る地下水面からの距離, 起伏量, 土培硬度, 粘土・シルト・砂の 各割合，全炭素拉よび全窒素を用い，さらに，放牧砂丘地，禁牧 10 年および 20 年の 3 調查地区の区分を類別変数（Nominal variable）として加えた。

表-3にCCA の 1 軸（固有値 0.50）および 2 軸（同 0.33）
での解析結果を要約した。種組成と環境要因との相関は，1軸で

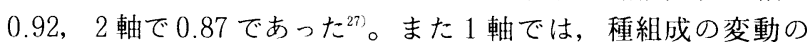
$9.5 \%$ ，種組成之環境要因の関係の $33.7 \%$ を 2 軸では前者の $6.3 \%$ ，後者の $22.5 \%$ をそれぞれ説明すると解釈された ${ }^{28)}$ 。環境 要因との相関をみると, 1 軸では, 砂含量や $\mathrm{N}$ など, 土壌養分 や粒径組成を示す变数が高い値を示した。また，禁牧 20 年の地 区とも高い相関を示したことから，1軸は土壤回復の程度を総合 的に指標する軸であると解釈された。一方， 2 軸では 1 軸ほどの 高い相関はみられないものの, 地下水面からの距離や土㙵硬度之 いった，地形条件や土嚊の物理性を示す变数と比較的強い結びつ きがみられ，植生・土壤回復に及ぼす地形条件の影響が示唆され た。両軸について Unrestricted Monte Carlo permutation testを行った結果，有意な結果が得られた（P<0.02）。

図ー3に，CCA によるサンプルおよび環境変数のスコアを 1 軸之 2 軸の座標平面上に配列した。環境変数はべクトルで表示さ れ，その長さおよび方向がそれぞれの軸との関連性を示すため, 同一平面上にプロットされたサンプルとの関係を直接把握するこ とができる゙ ${ }^{222233}$ 。サンプルは 1 軸上で, 放牧砂丘地および禁牧 10 年のサンプルと, 禁牧 20 年のグループに大きく分けられ，マイ ナス側ほど土壤の回復が進行したサンプルと解釈された。つぎに, 上述した植生・土壌回復と地形条件の関係をより明確にするため, 調査地区ごとに, 各サンプルの地下水面からの距離と CCA 1 軸 のスコアの関係をプロットした（図一 4)。これをみると，砂丘 放牧地㧍よび禁牧 10 年では，1軸のスコアは地下水面からの距 離が大きくなるにしたがい増加する傾向を示したが，禁牧 20 年 では, 地下水面からの距離の大小にかかわらずマイナス側でほぼ

\begin{tabular}{|c|c|c|}
\hline 軸 名 & 1 & 2 \\
\hline 固有值 & 0.500 & 0.333 \\
\hline 種組成－環境要因の相関 ${ }^{27)}$ & 0.918 & 0.869 \\
\hline \multicolumn{3}{|l|}{ 分散 (\%) ${ }^{28)}$} \\
\hline 種組成データ & 9.5 & 6.3 \\
\hline 種組成－環境要因の関係 & 33.7 & 22.5 \\
\hline \multicolumn{3}{|l|}{ 環境変数の各軸との相関 } \\
\hline 対照区 & 0.398 & -0.091 \\
\hline 禁牧10年 & 0.532 & $0.442(3)$ \\
\hline 禁牧 20 年 & $-0.788(3)^{※ 2}$ & -0.331 \\
\hline 地下水面からの距離 $(\mathrm{RH}) ※ 1$ & -0.053 & $-0.667(1)$ \\
\hline 起伏量（RL） & 0.234 & -0.364 \\
\hline 土壌硬度（SH） & -0.480 & $0.652(2)$ \\
\hline 粘土（CL） & -0.737 & 0.219 \\
\hline シルト（SI） & -0.676 & -0.106 \\
\hline 砂（SA） & $0.799(1)$ & -0.097 \\
\hline 全炭素（C） & -0.785 & 0.139 \\
\hline 全窒素（N） & $-0.798(2)$ & 0.153 \\
\hline
\end{tabular}

$※ 1$ : 環境変数の略名

※ : 各軸ごとに絶対値の大きい順番を示す. 


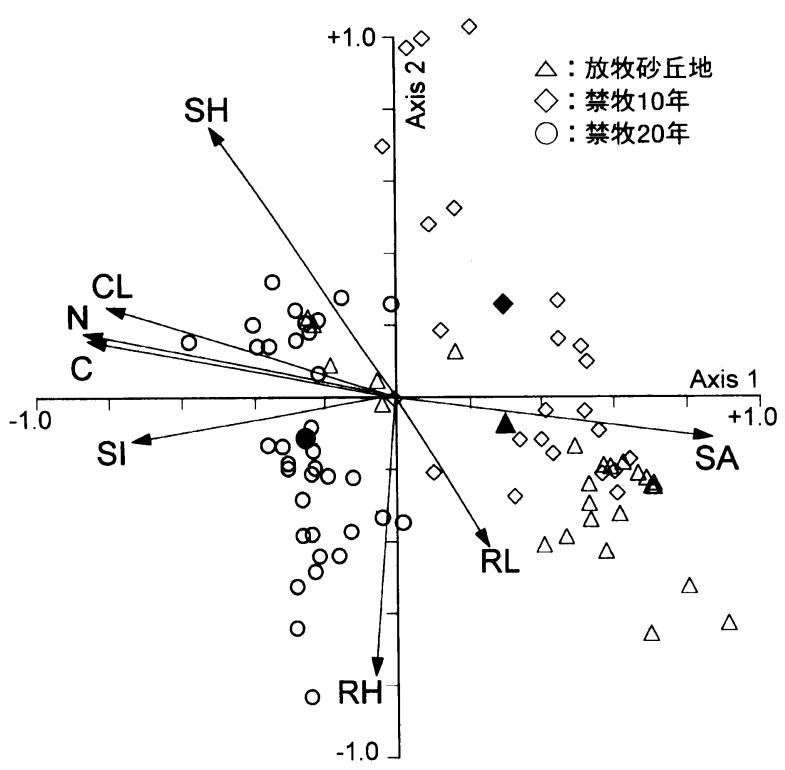

図ー3 CCA によるサンプルおよび環境変数の 1・2 軸のスコア 環境变数の略名は表 -3 荾照

黒澵りのマークは各調查地区のサンプルスコアの重心を示す

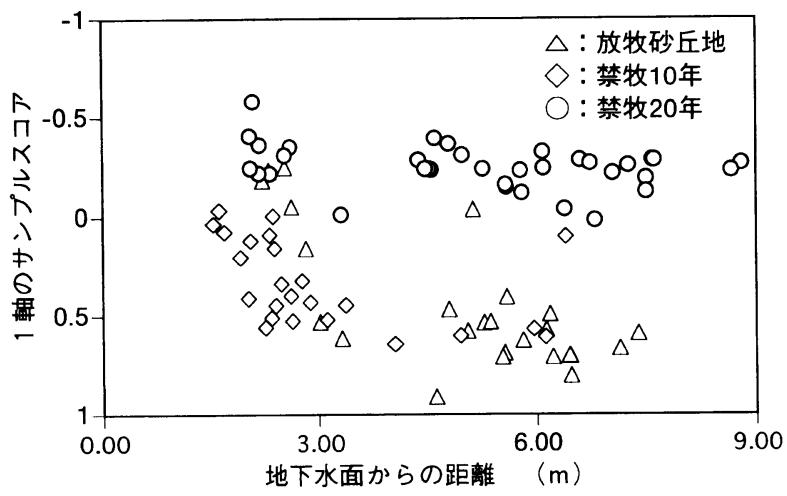

図一 4 各調查地区におけるサンプルの地下水面からの距離と CCA 1 軸のスコアとの関係

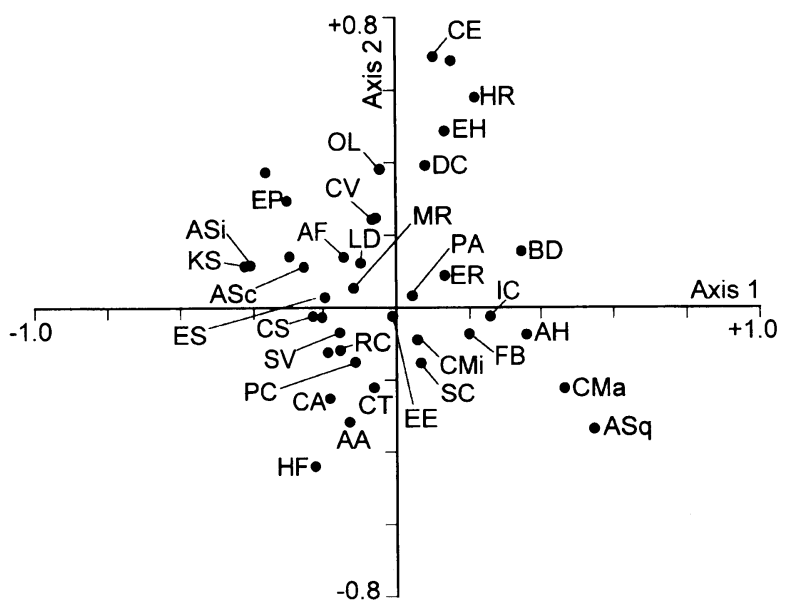

図ー5 CCA による種の 1・2 軸のスコア 図中の記号は学名の頭文字を示す (表一1の略名参照)

一定の值を示した。図一 5 は, 種のスコアを図 -3 と同様の平面 上に配列したものである。これをみると, 各軸上に沿った種群の
明暸な区分はできなかったものの, Agriophyllum squarrosum, Corispermum macrocarpum, Artemisia halodendron ど, TWINSPAN 分類の 3 P に多く出現する種が 1 軸上のプラ ス側に配列され，Artemisia frigida，Cleistogenes squarrosaなどの 3 の区分種はマイナス側にみられる傾向を示 した。2 軸上では，砂丘間低地などの湿性の立地に分布するとさ れる Calamagrostis epigeios ${ }^{(i)}$ が高いスコアを示したのが特徵 的であった。

\section{4. 考察}

\section{（1）植生分布の立地間差異}

ステップ草原の植生配列は，地形条件に対応していることが多 ( ${ }^{375)}$ 。本研究でも平沙地之砂丘地の植生は, 禁牧年数にかかわ らず，TWINSPAN の第 1 分割で明膫に区分された（表一2）。 このことは, 植生分布とその動態が, 地形タイプによって大きく 異なることを示している。そこでまず，こうした植生分布の差異 に影響を及ぼす環境要因について考察する。

砂斥地では，砂丘中〜上部を中心として，Artemisia spp.等 の灌木が優占する群落タイプがみられたのに対し，平沙地ではこ うした植物の侵入・優占は認められず，イネ科の草本を中心とし た群落タイプが形成されることが確認された（表一 1 )。砂地草 原では, 放牧による踏压の影響が地形条件によって異なり, 起伏 の大きい場所では土壤表面が摜乱される傾向があるのに対し, 平 坦な場所では土袞の緊密化が進むとされる ${ }^{17)}$ 。本調查でも, 放牧 平沙地の土壌硬度は, 起伏の大きい砂丘地の $3 \mathrm{P}$ のスンド群と 比較して高い値を示した。さらに, 粘土や $\mathrm{C}, \mathrm{N}$ の含量も $3 \mathrm{P}$ より多かった (表 -2$)$ 。土壌の粒径組成や養分の変動は, 砂丘 再活動之密接に関連しており ${ }^{26)}$, また, 細粒の土壤粒子が飛散し て流動化した砂丘では, Agriophyllum squarrosum や Artemisia halodendron等のような, 砂の移動に適応した生 理生態的特性を有する植物以外は生育が困難になるなど1314116), 植物の侵入・定着にも影響を及ぼすと考えられる。これらのこと から, 平沙地之砂丘地での踏圧に対する表層土壌への影響や, 表 層土堹の残存程度の差異が, 植生分布を規定する重要な要因であ ることが推察された。

ところで砂丘地では，斜面の相対的位置により植生がさらに区 分された（表一2）。砂丘下部では，放牧管理が行われていない 放牧砂丘地においても高い粘土含量を示すなど, 砂丘中〜上部之 は異なる土㙵特性を呈したことから（表一2），ここでも土壌理 化学性の差異が植生配列に影響を及ぼしていることが示唆された。 一方, 砂丘の上部から下部にかけての植生配列に関しては, 上述 したように，主として地下水面からの距離に基づく水分条件との 関連から論じられることが多い(1420)。砂丘地において, 地下水が 土壌水分に顕著な影響を及ぼすのは地下水面から $1 \mathrm{~m}$ 程度までで あるが， $3 \mathrm{~m}$ 程度まではわずかに影響が残るとされている ${ }^{12)}$ 。本 調查地区における地下水面からの距離は, 最低でも $1.5 \mathrm{~m} \sim 2 \mathrm{~m}$ 程度であり，地下水からの影響をそれほど強くは受けない範囲に あると考えられる。しかし砂丘下部の一部では Calamagrostis epigeiosのような種も出現し（図一5), また現地の観察では, 土壤が半湿の状態に維持されている場所むみられ, 地下水からの 若干の影響が認められた。

したがって本調査地区での砂丘地における植生配列には, 斜面 位置に対応した土䁃特性の差異とともに，水分条件の差異もある 程度影響を及ぼしているものと考えられた。

(2) 植生・土壊の回復プロセスと土地利用ポテンシャル

中国北部の砂漠化地域では一般に, 年降水量が 250 $500 \mathrm{~mm}$ 程度あれば人為的インパクトを除去することで植被の回復が十分 期待できるとされている ${ }^{26)}$ 。流動砂丘化が進みつつあるカルチン 
沙地の砂丘地において屯，禁牧によって短期間で植被摔が増加す る例が報告されている ${ }^{10}$ 。しかし，植被率の増加がそのまま土地 利用ポテンシャルの回復につながるとは限らない。たとえば禁牧 10 年の地区では, 砂丘中〜上部の一部でも植被率の回復が認め られたが，そのほとんどが Artemisia halodendronの優占に よるものであった（表一1）。Artemisia halodendron はその 根系発達パターン等にみられる生態的特性により, 流動砂丘から 固定砂丘にいたるまで幅広い分布を示し ${ }^{1625)}$, 砂丘固定に有用な 植物とされている。また，こうした大型植物は看護植物として， 他種の侵入・定着を促進する効果も期待される ${ }^{8314}$ 。しかし，家 畜の嗜好性は低いため, 植被が回復しても牧養力は依然として低 いと考えられる。したがって，土地利用ポテンシャルを評価する ためには，バイオマスのみならず種組成の変化も考慮する必要が ある。こうした点をふまえ, 地形タイプごとにみた植生・土壤の 回復プロセスを以下に考察する。

まず砂丘地をみると，砂丘中部～上部の植生は，禁牧年数にと もない組成的には $3 \mathrm{P}$ から $3 \mathrm{~N}$ ， 砂丘下部ではサンプル数に ばらつきがあるもののお抢むね $3 \mathrm{~N}$ から $2 \mathrm{P}$ へとれぞれ変化 する傾向を示した。砂丘中〜上部にみられる $3 \mathrm{~N}$ は, 固定砂丘 の指標植物とされる Artemisia frigida ${ }^{(2: 26)}$ 等によって区分さ れており，イネ科多年草の Pennisetum centrasiaticum や Cleistogenes squarrosa 等の生育も認められ（表一1），また 植被率も高いことから (表一-2), 組成, 構造ともに植生回復が 進んだスタンド群と考えられる。これに対し， $3 \mathrm{~N}$ は Artemisia halodendron を主体としつつ, 流動砂丘の指標種 である Agriophyllum squarrosum ${ }^{23}$ 等により区分されている ことから, 流動砂丘化の危険性が高く, 牧養力の低いスタンド群 と考えられる。

禁牧年数との関係をみると, 禁牧 20 年ではほとんどのサンプ ルが $3 \mathrm{~N}$ に含まれているのに対し, 禁牧 10 年までは放牧砂丘地 と同じ 3 P の段階にとどまっていた（表－2）。このことから， 砂丘中〜上部での植生回復には, 10 年程度の放牧管理では不十 分であることが示唆された。

方, 土锖の回復についても，禁牧 20 年と禁牧 10 年以下では異 なる傾向を示した。Liu et al. (1990) ${ }^{11)}$ やZhu et al. (1988) ${ }^{26)}$ に よ机ば，砂丘活動がほほ停止している砂丘地（固定砂丘）の土壤で は，シルト以下の細粒子の含量が $10 \%$ 程度，有機物含量も 0.5 〜 1\%程度になるされているが，砂丘中〜上部でこれらに近い值 に達したのは禁牧 20 年のみであった（表一2）。CCA の結果で も, 禁牧 20 年は他の地区とは 1 軸上で明瞭に区分され（表一 3 , 図-3), 地下水面からの距離の大きい地点でむ低い1 軸スコア 值を示した $($ 図一 4)。これらのことから，土壌の回復について も，砂丘中〜上部では植生回復と同様に 20 年程度の期間を要す ると考えられた。

以上の結果およびこれまでの報告から, 砂丘地における植生・ 土壤の回復プロセスをまとめると，砂丘中〜上部ではまず
Artemisia halodendron等の砂丘植物の残存株あるいは侵入 個体群の繁茂により表層が被覆され，その後に細粒物質の堆積・ 土壌養分の蓄積による土壌の回復および種組成の交代が進むもの と考えられた。また，前者のプロセスについては $5 \sim 10$ 年，後 者はさらに 10 年程度の期間がそれぞれ必要と考えられた。

これに対し砂丘下部では，禁牧の行われていない放牧砂丘地に おいてあ，組成的にはすでに $3 \mathrm{~N}$ に含まれており，また土壌に ついても上述の固定砂丘に近い構造を示した（表一2）。したがっ て砂丘下部では, Takeuchi et al. (1995) ${ }^{20}$ が指摘したように, 放牧停止により直ちに回復へ向かうものと考えられる。また，平 沙地においても，上述したように表層土堹が比較的良好な状態で 残仔しているため, 砂丘下部之同梯に短期間での回復が可能であ ると考えられる。

最後に, 地形タイプごとの回復プロセスをふまえ, 放牧を中心 とした土地利用のあり方について検討する。

まず砂丘地では，一旦表層が破壊されると回復に長期間を要す るため, 注意樑い利用が望まれる。砂丘下部の平坦面は比較的安 定しているため, 適度な放牧利用が可能である。これに対し, 流 動砂丘化しつつある砂丘斜面中〜上部では放牧を禁止する必要が あるが，加藤ほか $(1995)^{8}$ が指摘したように, 固砂植物の植栽 を併用することで，禁牧期間の短縮が期待できると考えられる。 また砂丘地では, 種組成からみた植生の回復が土壤の回復とほぼ 対応して推移していることから（表一 2 , 図-3), 植生を指標 とした砂丘安定度の評価や, 土地利用可能なサイトの診断をする ことができると考えられる。この場合, Artemisia frigida等 の指標植物群の出現程度やイネ科多年草の優占程度などが有効な 尺度としてあげられよう。

一方, 平沙地では, 砂丘地と比較して牧養力は高いと考えられ る。しかし, 組成的には地下部バイオマスの小さい 1 年生草本が 主体となるため, 土壤侵食に対する危険性は決して無視できな (18)。したがって, 放牧を行う際には, 根系の発達を著しく阻害

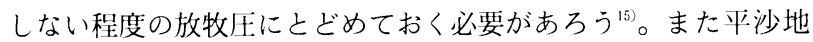
では, 短期間の禁牧によって, 種組成, バイオマスの両面から顕 著な植生回復が可能であることから ${ }^{17}$, 放牧の際には禁牧を含め たローテーション利用等を取り入れることが, 飼料生産性を維持 する点からも望ましいと考えられる。

以上のように, 脆弱な土地自然特性をむつ砂地草原地域に扔い て，土地荒廃を防止しつつ持続的な土地利用を継続するためには， 地形タイプごとに土地ポテンシャルをふまえた適正な利用を図っ ていく必要があると考えられた。

最後に, 本研究を行うにあたり中国科学院沙漠研究所趙哈林氏, 李勝功氏, 元同研究所徐斌氏, 農業環境技術研究所松尾和人氏に は現地調查で多大なご協力をいただいた。また，土壌試料の分析 に際しては農業環境技術研究所小泉博氏, 平館俊太郎氏に愳切な ご指導を賜った。以上の方々に心よりお礼申し上げる。

\section{引用文献及び補注}

1) 土壌標準分析・测定法委員会編 （1986）：土壌標準分析・测定法：博 友社, $354 \mathrm{pp}$.

2 ）福原道一（1995）：東アジアにおける 土地荒廃：Proc. International Workshop on Land Use System for Combating Land Degradation in East Asia, 5-10.

3 ) Hayashi, I., Jiang, S. and Nakamura, T. (1988): Phytomass production of grasslands in Xilin River Basin, Xilingol, Inner Mongolia, China: Bull. Sugadaira Montane Res. Cen. 9, 19-31.

4) Hill, H.O. (1979) : TWINSPAN A FORTRAN program for arranging multivariate data in an ordered two-way table by classification of the individuals and attributes. Cornell University Press, Ithaca, New York, 60pp.
5) Hongo, A., Matsumoto, S., Takahashi, H., Zou, H., Cheng, J., Jia, H. and Zhao, Z. (1995): Effect of exclosure and topography on rehabilitation of overgrazed shrub-steppe in the loess plateau of northwest China: Restoration Ecology 3, 18-25.

6) Jiang, D. and Kou, Z. (1995): Control of moving sand dune and restoration of vegetation in 
Wulanaodu region : Proc. International Workshop on Land Use System for Combating Land Degradation in East Asia, 153-163.

7 ) 門村 浩 (1985)：土地改変研究への 環境地形学的アプローチ：第四紀研究 24(3), 157-166.

8 ）加藤和弘・武内和彦・南寅鎬 - 冠振武 （1995）：中国内蒙古・クルチン砂地 における植生の退行と回復：Proc. International Workshop on Land Use System for Combating Land Degradation in East Asia, 165174.

9 ）加藤和弘（1996）：生物群集の多变量 解析とその地域環境計画への応用: う ンドスケープ研究 60(1)，46-55.

10）川鍋祐夫・蒋徳明・押田敏雄・冠振武・ 南寅鎬（1996）：内蒙古ケルチン沙地 における沙丘の固定・緑化の新方式： 日本草地学会誌 41(4), 360-363.

11) Liu, X., Zhao, H. and $X u, B$. (1990) : Mechanism of destruction and restoration of the grassland ecosystem in the Korqin Steppe region: Proc. the Third International Conference on Desert Development, 1-32.

12）増田拓朗・小林達明・吉川賢・森本幸 裕・小橋澄治（1988）：毛烏素沙地に おける土壌水分条件：緑化研究 10 , 30-41.

13) Nemoto, M. and Lu, X. (1992): Ecological characteristics of Agriophyllum squarrosum, a pioneer annual on sand dunes in eastern Inner Mongolia, China : Ecological Research 7, 183-186.

14）根本正之・魯暁雲・李勝功・劉新民 （1992）: 内蒙古東部半乾燥地の砂丘植 生におよぼす放牧の影響：日本草地学
会誌 38(1)，44-52.

15）根本正之 - 大黑俊哉 - 徐斌 - 趙哈林 （1994）: 綿羊の放牧の違いが数種草原 植物の生育に及ぼす影響一内蒙古半乾 燥地草原での事例：日本草地学会誌 40(3), 239-245.

16) Ohkuro, T., Nemoto, M., Lu, X., Xu, B. and Liu, X. (1994): Ecological characteristics of three native species grown in semi-arid grassland in eastern Inner Mongolia, China: Proc. the JapanChina International Symposium on the Study of the Mechanism of Desertification, 440-445.

17）大黒俊哉・根本正之（1996）: 中国北 東部半乾嬠地域の砂地草原における過 放牧による植生退行過程：第 10 回環 境情報科学論文集, 31-36。

18) Petit, N.E., Froend, R.H. and Ladd, P.G. (1995): Grazing in remnant woodland vegetation: changes in species composition and life form groups: Journal of Vegetation Science 6, 121-130.

19）武内和彦（1991）：地域の生態学：朝 倉書店, $254 \mathrm{pp}$.

20) Takeuchi, K., Katoh, K., Nan, Y. and Kou, Z. (1995): Vegetation cover change in desertified Kerqin sandy lands, Inner Mongolia: Geographical Reports of Tokyo Metropolitan University $30,1-24$.

21）武内和彦（1996）：東アジアの土地荒 廃と持続的土地利用システムの確立： 農村計画学会誌 14(4), 3-6.

22) Ter Braak, C. J. F. (1986): Canonical correspondence analysis: A new eigenvector technique for multivariate direct gradient a nalysis: Ecology 67, 69-77.

23) Ter Braak, C. J. F. (1988): CANOCO-a FORTRAN program for canonical community ordination by partial detrended canonical correlation analysis, principal component analysis and redundancy analysis: TNO Institute of Applied Computer Science, Wageningen, 95pp.

24) UNEP (1992): World Atlas of Desertification: Edward Arnold, $69 \mathrm{pp}$.

25) Zhao, A. (1992): Root growth in vegetation in degraded rangeland in Inner Mongolia, China: M. Sc. thesis, Department of Ecology and Environmental Research, Swedish University of Agricultural Sciences, Uppsala, Sweden.

26) Zhu, Z., Liu, S. and Di, $X$. (1988): Desertification and rehabilitation in China: The International Center for Education and Research on Desertification Control, 222pp.

27）種組成データより得られたサンプルス コアと, 環境変数の線形結合のサンプ ルスコアとの相関であり, 各軸での種 と環境要因との関係の強さを示す。

28）種組成データの分散（\%) は，種組成 データのみの計算より得られた固有値 を用いて， $\lambda \mathrm{k} / \sum \lambda(\lambda \mathrm{k}: \mathrm{k}$ 軸で の固有値）により計算される。また， 種組成之環境要因の関係の分散（\%) は，環境変数に対する種組成デー夕の 加重回㷌 (weighted regression) より得られた固有值を用いて，上記と 同様の式により計算される。

Summary: The process of vegetation and soil restoration by grazing control was studied at desertified sandy grassland in semi-arid regions of northeast China. The 128 quadrats $(1 \mathrm{~m} \times 1 \mathrm{~m})$ were situated along the transects set on sand dunes and flat sandy lands differing in the duration of grazing control, and the surveys of vegetation, soil property and topography were conduced. TWINSPAN was performed for all samples to classify the floristic data. Canonical Correspondence Analysis (CCA) was also applied for the samples of sand dunes to explore the relation between vegetation restoration and environmental variables including soil property and topography.

The samples were classified into two types by the first division of TWINSPAN which reflects not duration of grazing control but topography. This result suggested that soil property including texture, organic matter, nitrogen, and moisture condition related to topography were the important factors that determine vegetation distribution and successional patterns. The result of CCA revealed that on sand dunes the process of vegetation restoration corresponded with that of soil restoration, and also varied with micro topography such as the position of dune slopes. The duration of grazing control required for the restoration was also different depending on topography. On flat sandy land and lower part of sand dune where surface soil still remained, vegetation would recover quickly by grazing control, while it would take about 20 years on the middle and upper part of dunes.

Those results suggested that the ecological evaluation of a carrying capacity at each land unit, e.g. landform unit, should be needed to maintain a sustainable land use at a sandy grassland in semi-arid regions. 